\title{
A FEMININE OF NO ONE'S OWN IN CHARLOTTE TÁBUA RASA
}

\author{
UM FEMININO DE NINGUÉM EM CHARLOTTE TÁBUA RASA
}

\author{
Eider Madeiros ${ }^{1}$, Letícia Simões Velloso Schuler², Mariana Pinheiro Ramalho e \\ Hermano de França Rodrigues ${ }^{3}$
}

${ }^{1}$ Universidade Federal da Paraíba, M.Sc. in Literature, PhD student at Programa de Pós-Graduação em Letras, Voluntary professor and lecturer, Brazil, e-mail: eidermadeiros@gmail.com

2 Universidade Federal da Paraíba, Undergraduate students in Portuguese Language Letters at Departamento de Letras Clássicas e Vernáculas, Brazil, e-mail: leticiaschuler6@gmail.com; ramalhomari@hotmail.com

3 Universidade Federal da Paraíba, Permanent Adjunct Professor at Programa de Pós-Graduação em Letras and Departamento de Letras Clássicas e Vernáculas, Brazil, e-mail: hermanorg@gmail.com

ART ICLE INFO

Article history:

Received 2020-06-05

Accepted 2020-06-20

Available online $2020-06-20$
Keywords: Body. Feminine. Transexuality. Psychoanalysis. Brazilian literature.

Palavras-chave: Corpo. Feminino. Transexualidade. Psicanálise. Literatura brasileira.

\begin{abstract}
This paper aims to essay an open and constructive dialogue between the very rupture that the trans female body evokes and the recent concept of "feminine of no one", through an inductive approach that the latter could make it possible to be kept in a state of infiniteness, of openness, of incompleteness, of nonwholeness, the aspect that characterizes the surrounding and expressive territories of each one of the specific bodies that allow themselves to be situated more leaned onto the feminine. Based on the contributions of Bento (2008), Jorge and Travassos (2018), from the brief precepts of Lacanian psychoanalysis, and on an interview with Leonardo Valente, the author of Charlotte Tábua Rasa (2016), we intend to discuss insofar how the body of a trans woman in a Brazilian politics fictional scenario would be able to draw the difficult boundaries on the discourses, possessions and the domains of language between the self and the other towards the trans-sexualities which dedicate their efforts to reinscriptions and the fissures that are celebrated through the transgressive resilience of the feminine.
\end{abstract}

RESUMO. O presente trabalho tem o objetivo de ensaiar um diálogo aberto e construtivo entre a própria ruptura que o corpo trans feminino evoca e o conceito recente de "feminino de ninguém", através da intuição de que este último possibilita manter em um estado de infinitude, de abertura, de incompletude, de não-totalidade, aquilo que caracteriza os territórios circundantes e expressivos de todo corpo que se permita situar-se mais para o feminino. Ao nos basearmos nas contribuições de Bento (2008), Jorge e Travassos (2018), a partir de breves preceitos da psicanálise lacaniana, e de entrevista realizada com o autor de Charlotte Tábua Rasa (2016), Leonardo Valente, propomos discutir até que ponto o corpo de uma mulher trans numa narrativa ficcional da política brasileira seria capaz de tracejar as difíceis fronteiras sobre os discursos, as posses e os domínios da linguagem entre $o$ si e o outro nas tran-sexualidades voltadas às reinscrições e às fendas que sagram-se através da resiliência transgressora do feminino. 


\section{Preliminary notes}

Among the countless questions that literature proposes to face and represent, we are led to believe that it is this desire, of leaning towards the inconveniently ropenò that much of what we find in fictional narratives tends to be a step ahead in the circumscription of these issues. The trans issue, in addition to intriguing common sense and weakening the real r̃gender ideologyò arises as a spot of discourse production where apparent oppositions, such as what distinguishes what is feminine and what is masculine, are mixed.

Mixed with elements of current politics and fiction, the work chosen for analysis, Charlotte Tábua Rasa (2016), written by Leonardo Valente ï associate professor at Universidade Federal do Rio de Janeiro (UFRJ), and doctor in Political Science ï , brings with it the question of ñeminine of no oneò of the trans-woman's body in the face of angst crossed by subjective and internal dramas, and the relationship of the other to her own body. The statement of Charlotte, as the main character, brings along Flávia Vinî̄ presence, her wife and faithful partner, and also her personal advisersô Vitor and Denise, in addition to other names of fictional politics in Brazil; all as part of the scenario chosen by the author, made to build, during the narrative, the events that modulate Charlotte herself and Brazil's political heritance within its inside and out geographic space.

Faced with an election won already in place and a country eager for the first speech

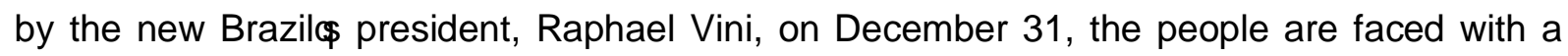
female figure, the most beautiful ever seen, who takes on the role of the greatest national political leader and shows her true identity: Charlotte Tábua Rasa, president of Brazil. Returning from a trip to Buenos Aires, with her wife Flávia, she announces on a national radio and television network the sex-change surgery, coming out once and for all with her new identity, from that moment on, alongside with being called by her ñwar nameơVALENTE, 2016, p. 8). The impact felt by the whole population was so high that attempts to take Charlotte's right to rule rise to uncountable times. However, as it was not an unconstitutional act, the president managed, in a way, to put her projects into practice, leveraging the Brazilian reality of true decay to a level of internationally prestigious homeland. Using sex to protect her own interests and the projects planned for Brazil, Charlotte breaks paradigms and clichés, showing herself to be an exemplary president, showing the limits that the country could cross. In contrast, she uses unorthodox methods, revealing that everyone has facets, that no one is totally good or totally bad, but surely something in between or beyond.

The thematic choice, for the analysis of our corpus, was based on the following questions: what did the transformation, made clear in Charlotte's m̃ew bodyò bring such of overwhelming, that keeps this body under scrutiny? If there is no inscription of sexual 
difference in the dimensions of the unconscious, for psychoanalysis, how does a body frransitatedòby changes that fix it in this mon-inscriptionòbecome more linked to the feminine than to its opposite? If Charlotte's body subverts the traditional male and female discourse and boundaries, would this body be hers alone and no one else's?

We intend, by choosing as a line of analysis that the ffeminine of no oneòconstitutes the horizons of the trans issue itself, to look after what would serve us to essay what Charlotte deconstructs and resignifies, from this threshold between what she was and what she proposes herself to be.

In a nutshell, the present paper, methodologically, seeks to pin down, from the fictionally constructed context, the presence of elements that leads us to a thematic reflection. From this, the research is guided by its objectives, being characterized as descriptive-explanatory and of theoretical and bibliographic character.

The treatment given to the corpus is notably qualitative, in its condition as an universe as a singular and specific literary work. In this perspective, the full work will be reduced, in the set of elements of the narrative, only to the character who stars and gives it the title it names. As Adorno (1991) asserts,

The essay, however, does not let its domain be prescribed for it. Instead of accomplishing something scientifically or creating something artistically, its efforts reflect the leisure of a childlike person who has no qualms about taking his inspiration from what others have done before him. (ADORNO, 1991, p. 4).

Therefore, all the concerns exposed here are not affiliated to the claim of postulating certainties, but, on the contrary, to cause the instability that is typical both of what emanates from literature, and of what borders on trans issues.

\section{Literary analysis and other reflections}

Etymologically, the English word "body" is derived from bodig and is related to the Old High German botah. From Latin, the Portuguese word r̃corpoò comes from the IndoEuropean dialect krp-es (from kpr-, or krep- r̃corpusò). Based on semantic studies, "body", then, means the physical structure of a living organism, which encompasses its physiological functions, whether that organism is a human or an animal. Just as Aristotle believed that in all corporeality there is a formation, some Platonists and Pythagoreans considered the body as the sepulchre of the soul. With Descartes, the being of thinking $i ̈$ the soul $i$ and the thing of the world $\ddot{i}$ the material body $\ddot{i}$ exist independently. The knowledge of man before the external world attracted the desire to explain, as clear and scientifically possible and with less mystery and mysticism, this deciphered cluster of human immanence and conflict. This 
certainty of a response without any doubt remaining, as Barbero and Pedernera (2016) brings us,

It corresponded to the Cartesian breaker paradigm that controls Western thought, and that clearly separates science from philosophy, as two worlds that will follow their courses in the form of parallel and independent paths. However, something came up and numbed the pure robservationa the presence of the observer that used to change the directions of study and, at the same time, ranimateòit $\ddot{i}$ in its double connotation of enthusiasm [to inspirit] and soul [anima] ï to the observer, this r̃subjectiveo that complicated the study and there had no explanation. (BARBERA; PEDERNERA, 2016, p. 5, our translation).

The emergence of psychoanalytic theory at the end of the 19th century began to privilege the subjective under new prisms and exposed the existence of an unconscious, an internal world as a postulate. Thus, the subjectivity of the object was fundamental for yet another decline in the subject's supreme objectification.

The self would be, for psychoanalysis, a kind of ñwo-facedò interface. One "is" a surface, while the other is the "projection" of a surface. The first, we characterize as being the ñbiological bodyò corresponding to the material reality, in which the needs that are defined by Biology arise. The second ñaceò is related to the psychic reality, called rerogenous bodyò containing in it the desires and marks of experiences, being a Psychoanalysisôñpatrimonyò

It is known that, for biological studies, "the body is the seat of inherited engrams that are carried out automatically in the surrounding world, which are denominated as 'instincts'". (BARBERO; PEDERNERA, 2016, p. 5, our translation). The psychoanalytic theory sows a seed of discord upon this, as some authors, such as Joyce McDougall (1981), affirm that the biological body and the erogenous body are intimately linked, being indissoluble, and needing to be treated as one, and no more as two. As the British poet William Blake (1971, p. 21) writes, rMan has no Body distinct from his soul; for that call@̂l Body is a portion of Soul discernôl by the five Senses, the chief inlets of Soul in this age.ò

This coming and going, which moves the different dimensions between the biological body and the psychic body, can represent the realization of an angst in inhabiting two bodies that, in general terms, does not cease. This non-dissociation between body and soul raises the following question: if there is no division between the biological and the psychic being, what would it have, then, between them? Jorge and Travassos (2018) take the same question, stating that

Because we are talking beings, our apprehension of bodily materiality goes through the experience of language, making us not to be reduced to our bodies. [...] There is an impossible distance to be bridged between the subject and their body and, therefore, the body en-scenes and en-bodies the subjective dramas concerning the 
psychic conflicts that could not be symbolized through words. (JORGE; TRAVASSOS, 2018, p. 19-20, our translation).

As beings who seek symbolization through words, we have, then, a body that claims a speech. And being a body, it is a matter ï to a certain magnitude $i ̈$ existed. Taking into account the bodily material, in the literal sense of the words, we come to the conclusion that great expectation is placed on what, in heteronormative issues, would be the final constituent of the individual: the sex genitalia of the baby. Loaded with greater importance than any other detail, rthe materiality of the body only acquires intelligible life when the sex of the fetus is announcedò(BENTO, 2008, p. 33, our translation), making the child, at the exact moment of their birth, already faced with a collection of expectations and events we return to their future, all designed for the fact of them being a girl or a boy. In other words, the original is already born contaminated by culture. Before being born, the body is already inscribed in a discursive field.ò(BENTO, 2008, p. 36, our translation). Therefore, in the case of this ready "formula", which the baby has to deal with from the beginning, "in this sense, the subject's psychosexuality is somehow a đ́olutionôi or, if we prefer, a symptom, in the psychoanalytic sense of the term: a formation of commitment $i ̈$ in the face of the multiple variables that the baby has to deal with since birth." (CECCARELLI, 2013, p. 19, our translation).

We see the importance of discourse in the construction of the subject's identity, which, even within a society that tries to put body and soul apart, instilling a compilation of norms since before their appearance in the physical world, also has the possibility to adapt itself to the needs and desires raise through what turns out imperative from psyche. Trans bodies carry their speeches as they express their own corporeality, and, therefore, the other individuals and cis society do not have the same capacity to create a discourse on these bodies, as they would always start from a normative and pathologizing speech. Berenice Bento (2008) brings us that,

\footnotetext{
What differentiates the performances of biological women / men and transsexuals is the legitimacy that gender norms confer on each of them, establishing, from there, a discursive dispute and an unceasing production of discourses on legitimacy of some exist and others are silenced and eliminated. (BENTO, 2008, p. 48, our translation).
}

The formation of trans subjectivity is always in conflict with the so-called maturalò with the sayings ñt is what it isò or r̃since the beginning of timeò because if for cisheteronormativity, what is named cannot be changed, it is in opposition to this that the trans body locates itself, that is, t̃the definition of what a 'true' man / woman is reflected and emerge in the definitions of what a 'true' transsexual isò (BENTO, 2008, p. 19, our translation). History is already loaded with an idea of producing pathologized identities, placing the individual in the middle of two exclusive possibilities of origin: either you have a 
penis or a vagina and from this on everything else must find sense. The transgender body, in its turn, establishes a relationship of identity construction from the insulting discourse, being m̃marked through and by the disputeòof recognition. (BENTO, 2008, p. 54, our translation).

To convey that transsexuality is an identity experience, which is related to the subjects' ability to build new meanings for men and women, does not mean forgetting the pain and angst that mark the subjectivities of those who feel and wish to live experiences that are forbidden by them not having behaviours considered appropriate for their sexes. (BENTO, 2008, p. 19).

Society, in its terms, has been undergoing several changes regarding the look at the theme of transsexuality, seeking to set a discourse, a semblance (LACAN, [1971] 2002), to the universal and homogeneous transsexual subject. We are, therefore, undergoing the updating of a concept that brings together all levels of the subject's subjective constitution to their biological body. While the normativity power screams loudly and shouts that transsexuality is pathological, the subject identified with their trans body evokes in their transidentity a discursive reality built by the rupture of norms, by gender performance, by nonbinary experiences and by what is intrinsic to the being of sexuality (eros) and an aesthetics of existence (psychē), linked between this physical body and the psychic body. (VENTURA, 2008). ñTranssexuality has a very peculiar characteristic that leads it to be considered a social phenomenon: it is marked by self-diagnosis and therapeutic self-prescription, that is, the subject self-identifies in a certain symbolic description.ò(JORGE; TRAVASSOS, 2018, p. 57 , our translation).

In this paper, making a funnel from the problems of the several trans bodies, we highlight the trans female body. The literary work in question, Charlotte Tábua Rasa (2016), brings, as the author himself told us, in a brief interview given by e-mail, for the elaboration of this text, the choice of a trans woman to govern the country appears as a way of breaking the patriarchal paradigms of politics, no matter if the wing is conservative or progressive, showing that government and state decisions require prepared and conscious human beings, regardless of gender and options. Following this line, Leonardo Valente still raises the question of advertising the body: after all, is the private body public or restricted to the private sphere, when we deal mainly with government officials? Charlotte, in the midst of the chaos installed after her appearance on television, before her inauguration, is accused first of all by electoral fraud, for having been elected still with the body of a cis man, as shown in the excerpt of the text:

¿ Should President Charlotte stay in power or not? Given all that has happened, is her mandate legal? And if it is legal, is it legitimate?

Tadeu was the first to respond: 
$\delta$ She must leave, either because Congress or the Superior Electoral Court considers what happened to be illegal, or because she is immoral, an electoral fraud. She needs to resign. (VALENTE, 2016, p. 64, our translation).

In view of this situation, the author considers it worthwhile to raise some questions such as: would the decision on the fate of the body itself be an electoral fraud? Who does the voter vote for, anyway? For a body? Charlotte not only permeates this accusation throughout the narrative, but also places her body as belonging to anyone but her. Party members, voters, diplomats, and other presidents feel they have the right to decide for themselves what to do with a body that should be taken only by the one to whom the body actually belongs. Being woman is an existence already crossed by so many questions, which are either wrongly answered, or an answer is never to be found, if it must be found anyways. In front of this, we put the angst and the emptiness felt by the body of a trans woman who, like Charlotte $\ddot{i}$ in addition to being a collection of feelings $\ddot{i}$, is still crossed by the other $\hat{\mathbf{s}}$ desire to take away for them what belongs only to her. Therefore, we come to the question: whose, then, would this feminine be, if it is not Charlotte $\hat{\mathbf{S}}$, nor from the external to her? Would this feminine belong to no one?

Branco (2019) opens space for a precious reflection around our intentions, when, by appropriating the figure of the f̂eminine of no oneò based on the poetry of Portuguese Maria Gabriela Llansol, it enhances a fissure in the notion of feminine binary to masculine from a feminine ribeyondòthat would extrapolate the logic that undermines the phallic discourse of power and supposes that there is a gap in the feminine that distinguishes it from the order of what is absolutized and results in a primary notion of completeness.

The not-all of the Lacanian feminine ([1972-1973] 1998) that the author translates for her readings, is examined by an identity construction bias that is not only beyond, in the field of non-belonging, but also ñhroughò also in transit through an opening because it comes from outside, in a strange-foreign way to struggle with symbolic language, familiarly exiled.

The solution of a feminine that does not belong to anyone is ambiguous and endless, since it is prioritized through an equation that does not close, since it breaks with the nature of the organisms-figures, and that is also real. Going abroad with the famous Woolf $\hat{\Phi} A$ room of one's own (2015), we could also perceive that the possessive space of a room in what can be related to the domesticity of homeland, turns into a pulverized and more complex scheme of body politics, when a woman, trans as she is, has to overcome the very notion of patriarchy intertwined in male patriotism and show she lacks any trace of inferiority by being feminine and stronger than any patronizing from the other. The governance of a country by the hands of a re-invented public body (BENTO, 2017) in female housewifely domestic features leads us to the territory of transsexual experience as a frontier pointing out to

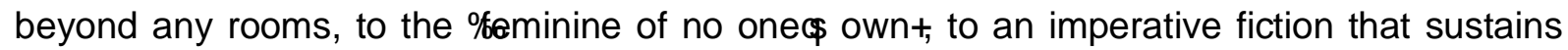


and rewrites our decreased reality, which cares too much about stablishing the private regulations of life and its own self deprivation in most of the its lacky structures.

In the midst of this, we put back in question, for the author of the book, the choice of the war name Charlotte brings us, in addition to being present in the title of the book. Valente tells us that ftábua rasaòalso has a symbolic relationship with the latin term tabula rasa, or from the English ñblank slateò since she is a new blank page in politics, written by Charlotte herself, but also circumscribed in the manufacture of the body shaved arbitrarily by the norms on this trans woman existence. The whole scenario is a new situation, unprecedented, in a conservative country marked by misogyny and prejudice that are well consolidated in the bases of society and, especially, of its elites.

In view of the questions about transsexuality that we brought up in the course of this paper, we can make the relationship between the blank slate and the trans body itself, which is assembled palimpsistically, that is, made by hand, but remade at the same time that it is

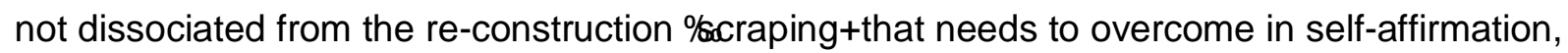
using, for this, specific techniques, which are able to draw and be remade on top of this îblank sheet of paperò Precisely because it is a manufacture, the trans body is both a transformation of what is innate, and the inscription of a body language that is its own, even if it is still suspended to no one $\hat{\boldsymbol{s}}$ own at the symbolic possibilities it announces without becoming completely symbolic.

Charlotte, therefore, in the midst of a game of belonging to herself and belonging to the other, ends up losing her first features during the narrative, becoming somehow mechanized, moved only to $\ddot{i}$ and by $\ddot{i}$ the pressure of the outside world, and often ceases to feel in the opposite movement, from the inside out, placing questions above herself that have nothing to do with her interior. However, when the new elections approach, when Charlotte is suffocated by the political and partisan events to which she has assigned, those around her combine the useful with the pleasant: she finds, in a political leadership strategy of the Gay Parade of Sao Paulo, a way of filling $\ddot{i}$ even if momentarily $i ̈$ what she felt was missing between her body and her soul.

It was a long time since the president liked an idea so much. That proposal was not just a campaign strategy, it presented itself as a gift, a way of being herself, of demonstrating herself as in the old days and exorcising her demons. Just thinking about the hypothesis, she felt stronger to start the electoral marathon. (VALENTE, 2016, p. 276, our translation).

There is a tortuous endless of possibilities that makes Charlotte, from giving herself to the public role and resisting along with her subversive corporeality, spin the economy of that feminine surrenders, or which surrenders to the other, to what is presumably lacking, not-all 
to the law, the symbolic, the patronizing, the order of body politics and conventions, in spite of her predecessor male physique condition. In this sense, the belonging of a fieminine of no oneòwhich is, above all, resilient, dilutes the crystallized conceptions of a limit for the making of bodies, shallow blank slate after all, and for the organization of any and all subjectivity, indecently affront and profound by their own.

\section{Some final considerations}

There remained two disturbing relations around the fieminine of no oneò when it migrated to the dimensions of the public political world, which Charlotte invaded, and which seemed emblematic of the effects that the female body presupposes when it is induced to the transit of its own affirmations. If a woman, while trans, walks along the paths of a moninscriptionòthat is external or assumed, it is because, to some extent, this is enigmatic for our own difficulty in dividing the body and what it materializes or summons from any psychic orientation in the formation of her identity, as well as it is elucidating the way in which the female body is taken as an object of transposition, between the dictate and the transgression.

Because it is not there, neither here, the assumption of the feminine in trans issues is essential to remove the notions of belonging from their conventional places. Emily Dickinson, in one of her most celebrated poems, announces the solitude and intrusiveness that remains on the border between recognizing and being recognized $i ̈$ even more so when from a woman of letters. ñ'm Nobody! Who are you? / Are you ï Nobody ï Too? / Then there $\hat{\Phi} a$ pair of us? / Don $\hat{\phi}$ tell! they $\hat{\emptyset}$ advertise ï you know! / How dreary ï to be ï Somebody! / How public $\ddot{i}$ Like a Frog ï / To tell one $\hat{\Phi}$ name $i ̈$ the livelong June $\ddot{i}$ To an admiring Bog!ò (DICKINSON, 1976, p. 133).

Fame, don $\hat{\phi}$ ask don $\hat{\phi}$ telling, the danger of going public due to being from a feminine placed at no one $\hat{\mathbf{s}}$, all is associated with no one as either inferior or impossibleé These are inviting elements to think about the realism that this m̃on-beingò which would derives of not "being-somebody", it is a place of comfort that comes from the risk of having to bring intimacy to the cruel popular judgment. A similar thing, from an unbearable disorder of the feminine to the intolerant context that was formed in terms of a Brazil chaired recently by a woman (cis, by the way), ends up showing the second relation of our uncanniness, with the description of the outcome of the Valente's narrative (2016). Let's see:

The crisis, unprecedented in decades, resulted in the impeachment of the then president, of an old center-left party shattered by corruption scandals. The vice president, who was from a center party and had been in power for decades, took over the government, but was unable to control the dissatisfied or to reverse economic problems. Shortly thereafter, with Brazil plunged into social upheaval and violence, conservatives won the elections and came to power. 
As soon as it took over the government, Salazar's party implemented a neoliberal and extremely austere economic primer, got closer to the United States, emptied relations with China and the BRICS, although it did not come out of any agreement, and sold virtually all pre-salt areas for English and North American companies. The measures, however, did not result in an improvement in the economic situation, nor did they stop the deterioration of public services, resulting in another five years of stagnation and crises. (VALENTE, 2016, p. 308, our translation).

Under the scribbles of concrete History or Charlotte's fictional narrative, it remains to be seen whether, by chance, there are traces of one or another sub-inscription that reveals, through fragments of hope transformed like a blank slate, the capacity of transit and remanufacturing of political as a body that, not being so much from anyone, expects from everyone to be able to remake themselves in a new guise, without forgetting to remake themselves in another challenging forms of self-recognition.

\section{References}

ADORNO, Theodor W. The essay as form. In: ADORNO, Theodor W. Notes to literature I. Translation: Shierry Weber Nicholsen. New York: Columbia University Press, 1991. p. 3-23. BARBERO, Luis Francisco; PEDERNERA, Maria Susana. Corpo 'biológico' e corpo 'erógeno'. Cartagena: Federación Psicoanalitica de América Latina, 2016.

BENTO, Berenice. A reinvenção do corpo: sexualidade e gênero na experiência transexual. 3. ed. Salvador: Devires, 2017.

BENTO, Berenice. O que é transexualidade. São Paulo: Brasiliense, 2008.

BLAKE, William. William Blake: creative will and poetic image. New York: Haskell House Publishers, 1971.

BRANCO, Lucia Castello. Feminino de ninguém: da escrita feminina ao feminino na escrita. Recovered at: https://17edu.org/pt-pt/feminino-de-ninguem-da-escrita-feminina-aofeminino-na-escrita/. Accessed in: 21 Aug. 2019.

CECCARELLI, Paulo Roberto. Transexualidades. 2. ed. São Paulo: Casa do Psicólogo, 2013.

DICKINSON, Emily. Iôn Nobody, 288. In: DICKINSON, Emily. The Complete Poems. Boston; Toronto: Little, Brown and Company, 1976.

JORGE, Marco Antonio Coutinho; TRAVASSOS, Natália Pereira. Transexualidade: o corpo entre o sujeito e a ciência. Rio de Janeiro: Zahar, 2018.

LACAN, Jacques. The seminar of Jacques Lacan, book XVIII: on a discourse that might not be a Semblance. Translation: Cormac Gallagher. Dublin: Lacan in Ireland, 2002 [1971]. 
LACAN, Jacques. The seminar of Jacques Lacan, book XX: Encore: on feminine sexuality: the limits of love and knowledge. Translation: Bruce Fink. New York; London: W. W. Norton \& Company, 1998 [1972-1973].

MCDOUGALL, Joyce. Cuerpo y metáfora. Revista de Psicoanálisis, Buenos Aires, v. 40, v. 5/6, 1983.

VALENTE, Leonardo. Charlotte Tábua Rasa. São Paulo: Pandorga, 2016.

VENTURA, Rodrigo Cardoso. A estética da existência: Foucault e Psicanálise. Cógito, Salvador, v. 9, n. 9, p. 64-66, 2008.

WOOLF, Virginia. A room of one's own. Chichester: John Wiley \& Sons Ltd., 2015. 